\title{
Reading the Bible in early eighteenth-century Dublin. The Huguenot pastor Henri de Rocheblave (1665-1709)
}

\begin{abstract}
Censors, book-burners, pornographers bear corrupt but unmistakable witness to the ambiguous mastery of texts over life.
\end{abstract}

GEORGE STEINER

Lire, c'est être ailleurs, là où ils ne sont pas, dans un autre monde. MICHEL DE CERTEAU

\section{RUTH WHELAN}

$\mathrm{T}$ The almanacs for 1686 provide arresting images of the triumphalism that swept through Catholic France when, on 17 October 1685, Louis XIV signed the edict of Fontainebleau revoking the edict of Nantes, which had granted legal status to Protestants for three generations. According to the almanac makers, who as usual were grinding a political axe,' the Revocation was foremost among the achievements of 'Louis le Grand, la terreur et l'admiration de l'univers' during the previous year. One of their images transmits a pithy political message about the way the Revocation was perceived, and was meant to be perceived, by the public. The main engraving portrays Louis XIV graciously acknowledging the submission of the Republic of Genoa, whose doge bows low before the French king (Figure 1). ${ }^{2}$ Under Louis's feet, significantly, the central cartouche illustrates the demolition of the temple at Charenton the place of worship for the Reformed community in Paris, which began on Monday 22 October 1685 and continued over the next six days (Figure 2). ${ }^{3}$ In art as in life, the systematic demolition of Protestant temples was as much about the submission, even the subjection, of the Huguenots to the king, as it was about their conversion to the king's religion.

1 M.G. Spencer, 'Almanacs and yearbooks', in A.C. Kors, R.L. Emerson, L. Hunt, A.J. La Vopa, J. Le Brun, J.D. Popkin, C. Bradley Thompson, R. Whelan and G.S. Wood (eds.), Encyclopedia of the Enlightenment (4 vols, New York, 2003), i, p.41 [hereafter, Encyclopedia of the Enlightenment]; also M. Préaud, Les effets du soleil. Almanachs du règne de Louis XIV (Paris, 1995), p.11.

2 For a summary of the unprovoked bombardment of the Republic of Genoa by the French, see P. Goubert, Louis XIV et vingt millions de Français (Paris, 1966), pp.205-06.

3 B.N. Estampes 72 C 52499; A. Spicer, "'Qui est de Dieu oit la parole de Dieu”: the Huguenots and their temples', in R.A. Mentzer \& A. Spicer (ed.), Society and culture in the Huguenot world 1559-1685 (Cambridge, 2002), p.175; O. Douen, La Révocation de l'Edit de Nantes à Paris (3 vols, Paris, 1894), iii, pp.571-91; S. Deyon, 'La destruction des temples', in R. Zuber and L. Theis (ed.), La Révocation de l'Édit de Nantes et le protestantisme français (Paris, 1986), pp.239-59; the engraving dates the demolition of Charenton as October 29, the day it was completed according to Douen. 
Figure 1: Louis Le Grand (BNF Estampes 72 C 52499 - by permission)

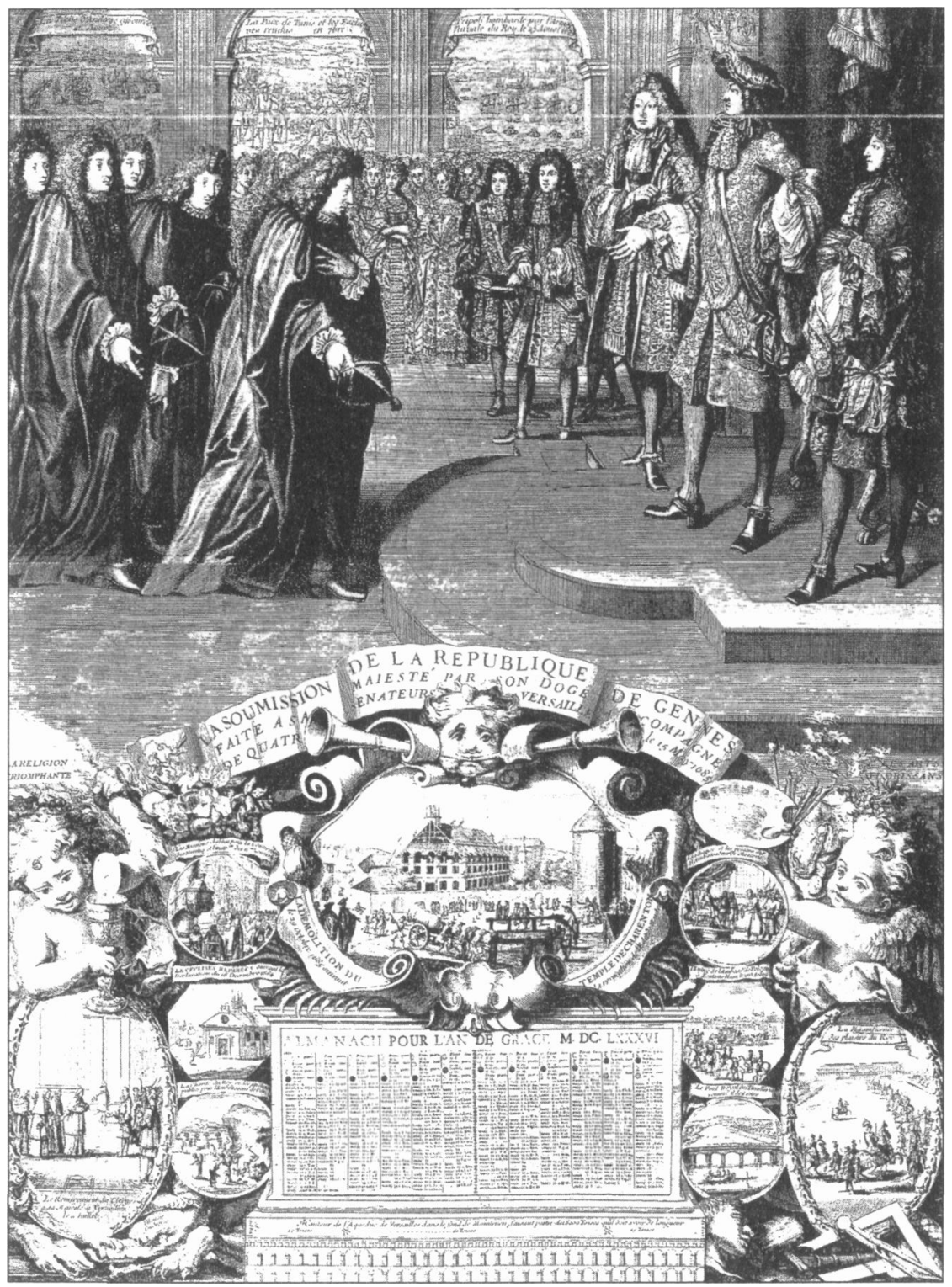

Clearly, the 'common people', who were the widest audience of almanacs in this period, ${ }^{4}$ were expected to recognise the subject and significance of the cartouche, which speaks volumes about the importance of Charenton, or of temples more generally, in early modern France. Temples, as Solange Deyon

4 Préaud, Almanachs, pp.11, 12; Spencer, 'Almanacs', p.41. 
Figure 2: Demolition of Charenton Temple (BNF Estampes 72 C 52499 - by permission)

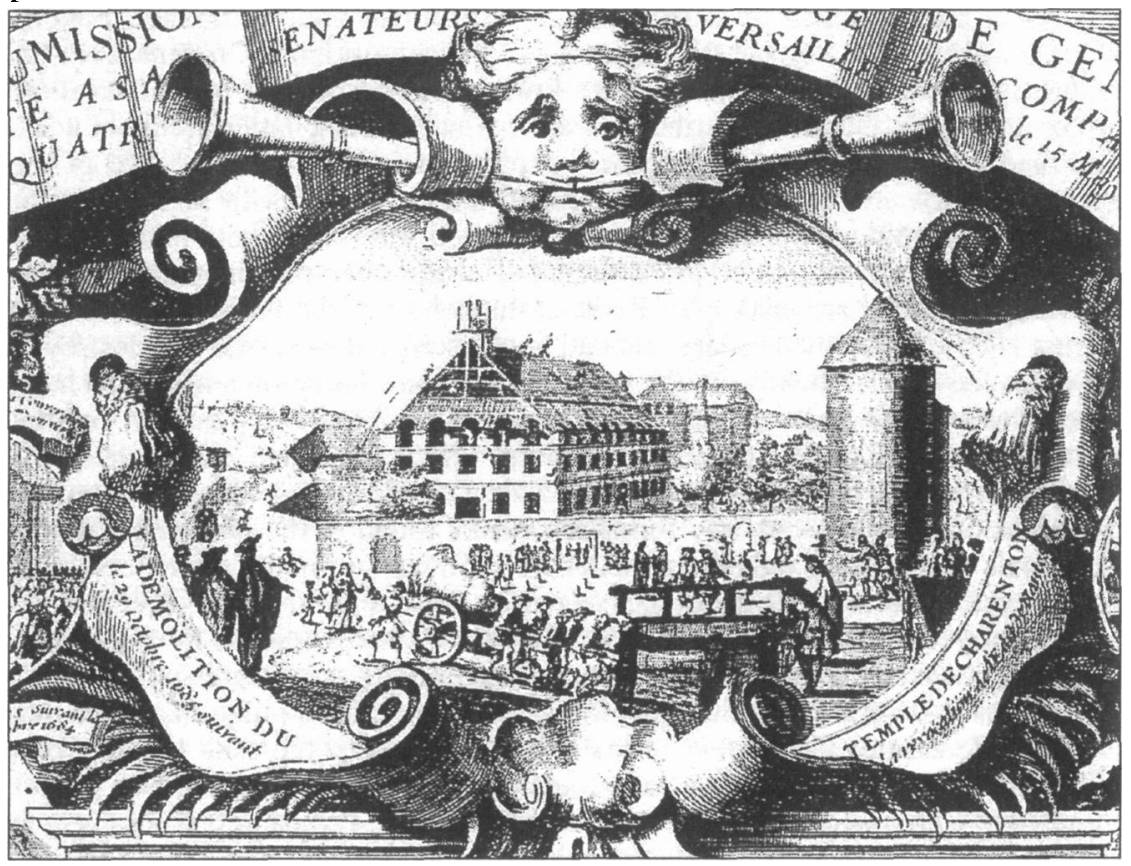

remarks, were a visual challenge in the towns where they were permitted, and they provided a powerful symbol of the presence of what the Catholic majority believed was a heresy in their midst. In 1656, the archbishop of Sens reminded the king of this in a speech where he referred to temples as 'des synagogues de Sathan', violent symbols built by heretics on the patrimony of 'le Fils de Dieu' 5 The feelings being expressed here by means of religious metaphors reveal how aware Catholics were of the significance of temple in the lives of French Protestants. Their religious and community life centred on their temples, and they were emotionally attached to them, which is why these buildings became targets for Catholic hostility and destructiveness. For example, in the early years of the personal reign of Louis XIV, that is, between 1661 and 1664,150 of an estimated total of 700 temples were destroyed, or between 20 to $25 \% .^{6}$ By the beginning of 1685 , a mere 10 to $15 \%$ remained open or standing. ${ }^{7}$ The temple at Charenton, because of the size of its membership, its distinguished pastors, and its proximity to the capital and the court, occupied a special place in the minds and hearts of contemporaries. In the engraving, the demolition of the temple at Charenton stands metonymically for the elimination of Protestant beliefs and practices from French society as a whole. At least, officially.

The noisiness of the destruction of Huguenot temples was but the latest and very public expression of a dynamic of exclusion at work in a political system -

5 Quoted by Deyon, 'Destruction des Temples', p.239; this is an allusion to Revelation 2:9, 3:9.

6 Rocheblave, Sermons, pp.241-42.

7 E.-G. Léonard, Histoire générale du protestantisme 1st ed. 1961 (3 vols, Paris, 1988), ii, p.370. 
the French version of absolutism - that constructed religious difference as dissidence. The persistent legal harassment of Protestants in the early modern period was accompanied by a stealthier assault on the sources of their beliefs, which is hidden from view in the engraving of the demolition at Charenton. In the temple enclosure were ten stalls, where Protestant bookbinders and booksellers - for example, Dupin, described as a 'maître relieur', and Étienne Lucas, described as an 'imprimeur et relieur' - plied their trade. ${ }^{8}$ On the eve of the demolition, officers of the Crown descended on Charenton with instructions to seize certain forbidden books, which they believed were being held in the temple precinct. A list of books to be proscribed had earlier been compiled by François de Harlay, Catholic archbishop of Paris, at the behest of the Paris parlement (29 August 1685), which then ordered that all books so listed be seized and destroyed (6 September 1685).${ }^{9}$ It was not the first time that the Charenton temple had been targeted as a consequence of this arrêt du parlement. On 27 September, Gabriel Nicolas de La Reynie, lieutenant general of police, had dispatched the commissioners Nicolas Delamare and Claude Lepage on a similar mission; on that occasion, to confiscate any forbidden books found in the personal libraries and homes of ministers and elders (i.e. church officers), or in the consistorial (i.e. church vestry) library. All the books seized on these and other subsequent raids were destroyed on 20 February $1687 .^{10}$ What books were these, so threatening to the fabric of society as to merit the repeated attention of parlement and police?

A sentence from the preamble to Harlay's list provides a pithy answer to that question. He assures the parlement that 'Nous [...] avons fait estat le plus exact qu'il nous a esté possible parmy cette foule de méchans livres, composez par les Luthériens, Calvinistes et autres Sectaires qui ont porté depuis plus d'un siècle la corruption dans le royaume'." The pathological metaphor is significant, although far from original. From the earliest days of the reformation, Protestants and Catholics alike used the analogy with illness to suggest that the other was a pollutant to their own understanding of the body religious or the body social, a morbid growth or cancer that had to be eliminated. ${ }^{12}$ And books, as Harlay affirms, were viewed as spreaders of disease. It is hardly surprising, then, to find the names of leading Protestant writers and polemicists on lists of proscribed books during the ancien régime, for example, Jean Calvin, Pierre Du Moulin, Pierre Jurieu, Pierre Bayle, Jacques Abbadie, Jean Frédéric Ostervald. In fact, according to Anne Sauvy, Protestantism dominates the market for forbidden books throughout the seventeenth and eighteenth centuries. ${ }^{13}$ What is more

8 Douen, Révocation, ii, p.138; M.M. Foot, The decorated bindings in Marsh's Library, Dublin (Aldershot, 2004), p.95.

9 Douen, Révocation, ii, p.139; A. Sauvy, Livres saisies à Paris entre 1678 et 1701 (La Haye, 1972), pp.3-4.

10 Douen, Révocation, ii, pp.133, 139.

11 Quoted by Sauvy, Livres saisies, p.4.

12 M.P. Holt, The French wars of religion, 1562-1629 (Cambridge, 1995), p.2; M. Greengrass, 'An Edict and its antecedents: the pacification of Nantes and political culture in later sixteenthcentury France', in R. Whelan and C. Baxter (ed.), Toleration and religious identity. The Edict of Nantes and its implications in France, Britain and Ireland (Dublin and Portland, 2003), pp.133-41.

13 Sauvy, Livres saisies lists books seized between 1678 and 1701. As late as 1746, Du Moulin's Anatomie de la messe (Genève, 1636) was seized in Bordeaux; see A. Sauvy, 'Livres contrefaits et livres interdits', in H-J. Martin and R. Chartier (ed.), Histoire de l'édition française (4 vols., Nantes, 1982-86), ii, p.110. 
surprising to the post-modern sensibility is the presence on these lists of Bibles - what are referred to as 'Protestant Bibles' - , biblical commentaries, psalm books, prayer books, and collections of sermons. In fact, 'Protestant Bibles' were among the most frequently confiscated books following the arrêt of 6 September $1685 .^{14}$ What is it about the Bible, or, indeed, books in general, that makes them the object of the licensed rage of a society? Why do institutions, interest groups, or even particular individuals find it so satisfying to act out that rage in unlikely places such as churches or even universities, under the ancien régime and even in our own time?

It is possible to give a variety of responses to such questions. However, in this essay I am concerned with looking at some of the ways those proscribed books were read, and particularly the Book - the so-called 'Protestant Bible'-, which was still widely accepted by early modern French Calvinists as the privileged narrative that gave access to ultimate meaning. This is not an easy task, as Robert Darnton pointed out twenty years ago: 'Reading has a history. But how can we recover it?' 15 My task is complicated by the fact that, unlike English Puritans, Huguenots did not keep diaries of conscience or other personal records that might provide direct access to the way they read their Bibles. ${ }^{16}$ Furthermore, few traces of the refugees who settled in Ireland survived the destruction of public records during the fire in the Four Courts in Dublin in 1922. Indirect approaches are necessary. I propose to use a posthumous collection of sermons preached by Henri de Rocheblave (1665-1709), at least some of which were delivered in the Lady Chapel of St Patrick's Cathedral, Dublin, as a way to begin recovering the history of reading in the Irish Huguenot Refuge. The sermons were published in 1712 by Isabeau de Rocheblave after her husband's untimely death, and may have been part of an attempt to secure patronage or a pension to support her and their three children. ${ }^{17}$ By applying insights derived from reader-response criticism to these sermons, it is possible to reconstruct the understanding of Bible reading that Rocheblave promoted from the pulpit to the French Protestants who met weekly for worship in the Lady Chapel. Knowing how pastors sought to mould people's relationship to their Bibles is an essential part, albeit only a part, of any history of reading. We shall see that although Rocheblave seeks to engage those who heard him preach in a potentially liberating interaction with the Bible, he also attempts to contain that interaction by framing it ideologically. ${ }^{18}$

14 Sauvy, Livres saisies, p.13; when the premises of Étienne Lucas were raided on 19 January 1685 , commissioner Delemare reported finding 1700 Pseaumes de Marot, 350 Nouveaux Testaments, 40 Bibles, and 400 prayer books, although these books had yet to be banned.

15 R. Darnton, 'History of reading', reprinted in P. Burke (ed.), New perspectives on historical writing (Cambridge, 1991), pp.141-67.

16 P. Benedict, 'Protestant and Catholic book ownership in seventeenth-century Metz', The faith and fortunes of France's Huguenots, 1600-1685 (Aldershot, 2001), p.153.

$17 \mathrm{H}$. de Rocheblave, Sermons sur diverses matieres importantes, ed. I. de Rocheblave (Amsterdam, 1712). In 1717, Isabeau, then aged fifty-two, appears on the list of the widows and orphans of 'poor distress'd French ministers' receiving allowances from the Royal Bounty Fund, all of whom were domiciled in England at that time. She received 121 ; see 'The Royal Bounty', Proceedings of the Huguenot Society 1 (1885-86), p.328 [hereafter, HSP]. For a summary of what is known of Rocheblave's life, see T.J. Kelley, Henri de Rocheblave: Huguenot minister in exile (unpublished M.Phil. dissertation, Trinity College Dublin, 1996).

18 The concern to control individual reading of Scripture by promoting a normative, clerical interpretation is present from the origins of the Reformation; see J.-F. Gilmont, 'Réformes protestantes et lecture', in G. Cavallo and R. Chartier (ed.), Histoire de la lecture dans le monde occidental (2nd ed. Paris, 2001), p.273-8 
Henri de Rocheblave is not the only French Reformed minister to have left a written trace of his preaching to congregations of Huguenot refugees in Ireland - far from it. However, this volume of sermons is a particularly appropriate source for the study of reading habits. Isabeau sums up her husband's preaching style in her preface by referring to his sermons as 'saintes méditations', that is, an act of contemplation focussed patiently on its object; and, later, quoting her husband, she refers to his preaching as 'explication de [...] texte'. ${ }^{19}$ This description is borne out by his practice. Rocheblave consistently preaches exegetical, expository sermons, in the plain yet strongly affective style (as opposed to the more rhetorically embellished preaching of, say, Jacques Abbadie, Dean of Killaloe) that was recommended for pulpit oratory in the French Reformed tradition. ${ }^{20}$ In other words, the ten extant sermons are readings of Scripture and provide a written record of a particular kind of reading practice. Furthermore, Isabeau remarks, perhaps sadly, that if her husband had been writing his sermons for publication he would undoubtedly have left them 'dans un meilleur état'. But death took him by surprise, leaving her to publish the sermons 'tels qu'ils sont', such as they were when she unearthed them from among his papers. ${ }^{21}$ The somewhat unpolished, unelaborated, and even unfinished flavour of the sermons confirms her assertion. ${ }^{22}$ This makes them an unusual source, a published record captured à l'état brut, as it were, that provides the kind of raw contact that we seek with the reading practices that inspired Rocheblave, and which he imparted to his listeners in what might be described as a collective act of reading. But can preaching be so described?

From its inception, the Reformed tradition gave to reading Scripture a centrality that the medieval church had reserved for communion and this at a time when literacy, as we know it, was confined to elites. Consequently, for the common people, even those with rudimentary skills, legere actually signified audire, turning reading into something that was - in Darnton's pithy phrase 'meant to be taken in through the ears', and was, more often than not, a collective and social activity. ${ }^{23}$ Reformed services were shaped by this reality. The liturgy centred on the Word. ${ }^{24}$ Extensive passages from the Bible were read aloud by the appointed reader, 'afin de donner au peuple la connaissance de l'histoire sainte [...] et sur tout l'intelligence des mysteres de nostre redemption', as the

19 Rocheblave, Sermons, unpaginated Preface.

20 R. Whelan, "'The foolishness of preaching": rhetoric and truth in Huguenot pulpit oratory', in M Magdelaine, M.C. Pitassi, R. Whelan and A. McKenna (ed.), De l'humanisme aux Lumières, Bayle et le protestantisme (Paris and Oxford, 1996), pp.289-300 [hereafter, De l'humanisme aux Lumières].

21 Rocheblave, Sermons, unpaginated Preface.

22 Rocheblave obviously had a tendency to get carried away when he entered the pulpit, possibly by the Scriptural examples, passages and verses that Isabeau says came crowding into his head - of which there is some evidence in the sermons. He does not always manage to finish expounding his text in the time available. For example, he carries over the fourth part of his first sermon. which he did not have time to develop, to the second sermon, turning the part into the whole. The sixth sermon in the collection was supposed to have two themes, but the second becomes the subject of the seventh sermon.

23 Darnton, 'History of reading', p.150; H.-J. Martin, Le livre français sous l'ancien régime (Nantes, 1987), pp.228-31.

24 This was the case in Ireland whether or not the refugees retained their French Reformed affiliation or accepted the French Episcopalian compromise, which was intended to be a prelude to full conformity to Anglicanism; see R. Whelan, 'Sanctified by the Word: the Huguenots and Anglican Liturgy', in K. Herlihy (ed.), Propagating the word of Irish Dissent, 1650-1800 (Dublin and Portland, 1998), pp.81-86. 
theologian and writer, Moïse Amyraut observed in $1647 . .^{25}$ The whole congregation sang psalms, in the Marot-Beza version, repeatedly throughout the service and, of course, listened to the minister's exegetical preaching, which occupied a central place in the service and provided what one commentator calls a lectio continua of the Bible. ${ }^{26}$ Consequently, whether in France or in Ireland, many did not distinguish hearing from reading the Bible. ${ }^{27}$

What this means is that Reformed services, with their emphasis on reading, singing, and preaching the Scriptures were promoting an active liturgical hearing, which was both individual and communal, and is one mode of the intensive reading practices typical of traditional societies in the early modern period. These are the practices whereby a few books were read and reread, recited, heard and memorised, and became deeply impressed on the consciousness of the readers, subjecting them to the authority of the text $\mathrm{t}^{28}$ - but not just to the authority of the text, in the case of the Bible. A Reformed preacher of exegetical sermons, like Rocheblave, appears in the text of the sermon as a kind of embedded reader, simultaneously modelling the kind of reading required of auditors, while, as a preacher, attempting to turn them - ex auditu - into the kind of reader he is himself. To borrow a phrase from Jean-François Gilmont, the sermon combines two kinds of Bible and Bible reading, 'la Bible de l'oil' and 'la Bible de l'oreille', with the printed Bible (which the preacher reads and interprets) functioning as a control on the oral Bible (which the congregation hears). ${ }^{29}$ Concomitantly, hearing exegetical sermons is an act of pre-digested reading for congregants who are guided through the complexities of the Bible by pastors, and caused to memorise biblical texts by the way preachers insistently repeat them in the course of the sermon. Preaching also provided a guide as to how the Bible and the passages explicated in the sermon were to be read, which means that congregants rarely if ever encountered an unmediated text. By studying the protocols of reading inscribed in Rocheblave's sermons, which direct but do not determine what may be called his hearer-readers, we can hope to recapture something of the range of responses that were being scripted for them and which were at least available and possible.

It is paradoxical to claim that Rocheblave, as the author of these sermons, is actually an embedded reader in the sermons he himself has written and preached. Yet this paradox takes us to the heart of the Reformed understanding of Scripture, Bible reading and preaching in the early modern period. To put it succinctly, Rocheblave believed, and repeatedly stated his belief, that Scripture is Godspeaking. As a careful exegete, he may comment on the context of the passage that is the subject of his sermon, draw his auditors' attention to the meaning of certain words in the Hebrew or Greek, or allude to the lives and assumptions of the writers of Scripture, pointing to the ways these factors influence their stories

25 M. Amyraut, Apologie pour ceux de la religion sur les sujets d'aversion que plusieurs pensent avoir contre leurs personnes et leur creance (Saumur, 1647), p.427.

26 M. Carbonnier-Burkard, 'Le temps de la Cène chex les réformés français (milieu du XVIe-début du XVIIe siècle)', in M.-C. Pitassi (ed.), Edifier ou instruire? Les avatars de la liturgie réformée au XVIe au XVIIle siècle (Paris, 2000), p.66, n.36.

27 R. Gillespie, 'Reading the Bible in seventeenth-century Ireland', in B. Cunningham and M. Kennedy (ed.), The experience of reading: Irish historical perspectives (Dublin, 1999), p.27.

28 R. Chartier, 'Reading and reading practices', in Encyclopedia of the Enlightenment, iii, p.400; Darnton, 'History of Reading', p.148.

29 Gilmont, Réformes Protestantes, p.278; R. Gillespie, Reading Ireland. Print, reading and social change in early modern Ireland (Manchester and New York, 2005), pp.139, 153. 
and views. ${ }^{30}$ But again and again he conflates the scriptural text with the voice of God, observing that 'le St Esprit remarque dans le livre des Juges'; 'c'est ainsi que le Psalmiste fait parler Dieu'; 'quoique David [...] parle [...] le St Esprit [...] conduisoit sa langue et sa plume'; 'Dieu parle au peuple juif par la bouche de Jeremie'; Jesus-Christ nous l'apprend [...] dans le texte que nous expliquons'; 'le $\mathrm{S}$. Esprit fit entendre cette voix à St Jean'; or, commenting more generally on the teachings of Scripture: 'la bouche de l'Eternel a parlé'.31 Although such views had for many years been subject to the critical scrutiny of scholars - whether Reformed or Roman Catholic - working in the burgeoning field of biblical exegesis, Rocheblave the preacher so runs together the notions of inspiration and revelation as to make God speak every word of Scripture..$^{32}$ This means that the preacher in an essentially exegetical tradition not only reads and interprets the biblical text but also hears it, since the words of the Scripture are the voice of God. The implications of an understanding of Scripture, which was still widespread in the French Reformed tradition at the time, are important.

In fact, Rocheblave ontologises Scripture, attributing to the words of the text a divine transcendence and real presence. ${ }^{33}$ Reading in this understanding is not information gathering, but rather an act of communion with God, first by means of the text, and then ultimately without it. As Wesley Kort remarks of Calvin's understanding of Scripture 'Lectio is inseparable from meditatio, from prayer and contemplation' ${ }^{34}$ This is why Isabeau describes her husband's preaching as a form of meditation and Rocheblave scripts his hearer-readers to respond meditatively to the teachings of Scripture. ${ }^{35}$ From this perspective, reading is personal encounter and relationship, with all the internalising and transforming power such a notion implies, and this is the case not only for preachers, but also for those who hear them preach. Rocheblave repeatedly states the way he expects his auditors to respond to the preaching and reading of the Bible. Scripture, in his view, requires from its hearer-readers an active apprehension or appropriation, and a visceral ingestion of the Word. ${ }^{36}$ 'Que ces divines paroles fussent profondement gravées dans nos esprits!' 'que cette parole produise en vous tous les effets auxquels elle est destinée, que tous les exemples [...] qu'elle propose fassent une profonde impression dans vos coeurs'; 'apliquez-vous à la lecture et à la méditation de la Parole de Dieu...'. ${ }^{37}$ This makes reading (and preaching)

30 For example, Rocheblave, Sermons, III, pp.61-62; IV, pp.92-93; IX, p.250, X, p.281 (context of the passage); IV, pp.93, 99, 102, 103; V, p.132, VII, p.193 (comments on Hebrew usage); X, pp.283, 287 (comments on Greek); III, p.61; VIII, p.215; IX, p.248-49; X, p.281-282 (life circumstance of authors).

31 In order of citation: Rocheblave, Sermons, I, p.17; II, pp.47-48; IV, p.102; I, p.2; VII, p.190 (the text is John 3.16, where the evangelist attributes certain words to Jesus); V1, p.175 (an allusion to Isaiah $1.20,40.5,58.14$ ).

32 On the theological implications of this, see W.J. Abraham, Divine revelation and the limits of historical criticism (Oxford, 1982), pp.1, 23

33 W.A. Kort, 'Take, read'. Scripture, textuality and cultural practice (Pennsylvania, 1996), p.86; and G. Steiner, Real presence. Is there anything in what we say? (London and Boston, 1991), pp.3-4.

34 Kort, 'Take, read', p.23; M. de Certeau, 'La lecture absolue. Théorie et pratique des mystiques chrétiens: XVle-XVIle siècles', in L. Dällenbach and J. Ricardou (ed.), Problèmes actuels de la lecture (Paris, 1982), pp.71, 79.

35 Rocheblave, Sermons, VI, p.152.

36 Rocheblave, Sermons, VII, p.182: Steiner, Real Presence, pp.8-9.

37 Rocheblave, Sermons, VIII, pp.212, 221, 244; the whole sermon, on the subject of the apostle Paul's farewell to the elders of Ephesus (Acts 20.32), is a sustained reflection on preaching and 
Scripture an 'intangling', as Milton expressed it ${ }^{38}$ which causes readers to inscribe themselves in the text and the text in themselves, the words are made flesh, becoming refined perceptions and felt meaning that may result in moral action. In the sentences quoted above, however, the Word is usually the agent and the hearer-readers the object - the grammar is no accident. Although hearer readers of Scripture have a responsibility to respond, Rocheblave, as a pastor in the Reformed tradition, insists that the power to respond appropriately to the Word comes from the Spirit, from grace, from what he calls on one occasion, 'cette assistance surnaturelle'. ${ }^{39}$

That is to say, Scripture reads its hearers and readers, searching them, becoming an agency in their consciousness, encountering them, empowering them, releasing - to use George Steiner's poetic phrase - 'its implosive powers within the echo chambers of the self' ${ }^{40}$ Yet, the preaching, hearing and reading of the Word are but the means, which the real agent, God, uses to create that inner, psychological space in the first place. ${ }^{41}$

There is a politics of reading ${ }^{42}$ at work here, and its implications are farreaching. Although Rocheblave expounds a selected passage in each of his sermons, he situates his text in a larger mosaic of explicit citations of other scriptural verses, or allusions to other events, books, characters and even phrases of Scripture. In her preface, Isabeau point to this as one of his characteristics, observing 'instruit dans les Saintes Ecritures dès son enfance [...] il les emploioit toûjours à relever l'éclat de ses discours, et [...] les passages lui venoient en foule d'abord qu'il s'agissoit d'apuier une vérité evangélique'. Rocheblave also repeats phrases or verses from the passage he is expounding in a sermon, 'intangling' himself and his auditors - collectively and individually - in the language, meaning and cadences of scriptural texts in French translation. ${ }^{43}$ Time and again, he urges his hearer-readers to follow his example: 'Lisez, Chrétiens, attentivement ces passages de l'Ecriture ...'; 'Lisez avec soin le V chapitre de St Matthieu, et vous verrez ...' ${ }^{44}$ Of course, some families did not have a Bible and many could not read, ${ }^{45}$ but it is important not to underestimate the power of

hearing Scripture; there is a kind of tragic irony in the fact that Rocheblave preached this sermon in the Lady Chapel of St Patrick's Cathedral, Dublin, in the second week of September 1709, the week of his unexpected death. For similar sentiments, see III, p.87; IV, pp.93-94.

38 Quoted by S.E. Fish, Surprised by sin: the reader in Paradise Lost (Berkeley, Los Angeles, London, 1971), p.21.

39 Rocheblave, Sermons, III, p.87; VII, pp.182, 206-207; VIII, pp.213-214, 238, 242; IX, p.268.

40 Rocheblave, Sermons, IV, p.102; VIII, pp.238-40; Steiner, Real Presence, p.10.

41 Rocheblave, Sermons, VI, p.154; VIII, pp.220, 223, 224, 239-41; K.P. Meyer, “"The last day I sate at this board...": Sermons recorded at Youghal, Bandon, and Mallow, 1676-1688', in Herlihy (ed.), Propogating the word, p.73.

42 See L. Pearce, Feminism and the politics of reading (London, New York, Sydney, Auckland, 1997).

43 It is possible that Rocheblave received negative feedback from his congregation about this habit of his, since he distinguishes the habit of repeating the words of Scripture in order to 'inculcate them into the mind' from the 'vain repetition' censured by Jesus (see Matthew 12.34); see Rocheblave, Sermons, IV, p.102.

44 Rocheblave, Sermons, VI, p.157; VIII, p.237

45 E. Labrousse and R. Sauzet, 'Les protestants', in J. Le Goff and R. Rémond (ed.), Histoire de la France religieuse, (4 vols., Paris, 1988), iii, p.479; Benedict found that $69 \%$ to $72 \%$ of Protestant households in Metz, for which inventories survive, had at least one book - in the majority of cases, a Bible; as opposed to $21 \%-25 \%$ of Roman Catholic households; see 'Book ownership', pp.163-5. 
memory in traditional societies with essentially oral cultures. Both literate and illiterate congregants were able to recite passages that they had come to know by heart, no doubt as a result of the intensive reading practices in which they participated ${ }^{46}$ In his preaching, Rocheblave is enacting himself, and inculcating into his hearer-readers, a structure of attitude that defined the Reformed tradition in this period. By insisting on the primacy of Scripture reading (or hearing, in the case of the illiterate) for every Christian, Rocheblave is, as it were, putting the Bible into the hands of ordinary people, re-enacting in his sermons - and no doubt throughout his life and ministry - the 'tolle lege, tolle lege' made famous by Augustine. ${ }^{47}$ The social and political consequence of this understanding of reading are obvious: 'a potential authority [is] given to every Christian by virtue of reading Scripture', as Wesley Kort observes, ${ }^{48}$ which shifts the structures of authority that prevailed in the medieval church.

This shift is exemplified not only in the way Rocheblave preaches, but also in the way he scripts his auditors' response. On the first Sunday in September 1709, he preached what turned out to be his last sermon, uncannily summing up his life's work in the following words: 'Il y a déja long-tems que nous travaillons à votre édification dans l'exercice du saint ministere', which he later alludes to as the 'ministére de [1] a parole' ${ }^{49}$ Pastors, as Rocheblave indicates, are ministers that is, servants - of the Word, and they, no less than their hearers, are equally subject to its authority. Rocheblave repeatedly addresses his hearers as 'mes frères' (the masculine was deemed to cover the feminine in this period), and slips easily from 'vous' to 'nous' in his sermons. Obviously, he situates himself among rather than apart, a preacher to whom the Word also speaks, who is subject to its authority, and open to its interrogation. ${ }^{50} \mathrm{~A}$ ritual gesture incorporated this structure of authority into the very being of the simplest of Reformed believers who met for worship, Sunday after Sunday. When the minister began to preach, there was a rustle of movement in the congregation as the men put back on the hats they had removed for the reading of Scripture and the prayer of illumination that preceded the sermon. Bare-headed before God but not before people who, however educated or consecrated, were human beings like unto themselves - all, without exception, subject to the authority and scrutiny of the Word.

This is the principle of sola Scriptura, central to the Reformation, which in theory places Scripture over rather than under church, over rather than under those who are ordained..$^{51}$ Yet the reality was not so clear-cut. Pastors are indeed hearers and readers of the Word in a community of hearers and readers, but their hearing and reading differs from that of their flock in the degree of learning they bring to understanding the sacred texts, as Jean Claude - one of the

46 For example, Élie Neau reminds his pastor Jean Morin of the text of one of his sermons (Genesis 32:26) that Neau had heard him preach some twenty years previously, [J. Morin], Histoire abbregée des souffrances du sieur Élie Neau, sur les galeres, et dans les cachots de Marseille (Rotterdam, 1701), p.179; Gilmont argues for the importance of oral transmission in the development of the Reformation; see Réformes Protestantes, pp.279-82.

47 Augustine, Confessions, VIII.12.

48 Kort, 'Take, read', pp.23-24.

49 Rocheblave, Sermons, VIII, pp.216, 223, 224.

50 Rocheblave, Sermons, IX, p.249, remarks on the humility that should characterise the minister of the Word.

51 Kort, 'Take, read', p.24; B.M.G. Reardon, Religious Thought in the Reformation (London and New York, 1995), pp.62-65, 89-92, 113-14, 139-40, 163-69. 
distinguished pastors and theologians at the Charenton temple before the Revocation - pointed out in $1673 . .^{52}$ As the lexis used by Rocheblave to describe his preaching indicates, the role of ministers as learned readers is to examine the Scriptures, meditate on them, and then, by preaching, draw their auditors into an attentive examination of the sacred texts..$^{53} \mathrm{He}$ also favours verbs and metaphors of seeing - 'je vous ferai voir' - to describe a process of instruction which should ideally be by way of illumination, causing all present to see a suprasensible reality with the incorporeal eye, 'les yeux de la foi', or 'les yeux de nôtre entendement' ${ }^{54}$ Thus, pastors are teachers and guides, instructing their flocks, and exhorting them 'que vous cheminiez selon Dieu' ${ }^{55}$ Even in Rocheblave's idealistic representation of Scripture reading a cleavage remains: the perceptions of a speaking clerical elite provide the silent congregation with the frames for understanding the biblical text. ${ }^{56}$ I return to these ambiguities and their implications below.

There is also an anthropology of reading at work in Rocheblave's sermons, that grounds his preaching to Dublin Huguenots in reality. Hearing, reading, and preaching Scripture are driven by a sense of lack, of something wanting, which Christian theologians explain by reference to the Fall. Rocheblave refers to the way 'les caractéres saints et glorieux de son [=Dieu] image' shone forth from Adam and Eve, 'nos premiers parens', 'dans l'état d'innocence', but 'aprés leur chute, cette image de Dieu a été presque entiérement effacée, son ouvrage a été tout defiguré'. ${ }^{7}$ The result was a dilemma affecting all human beings that Reformed theologians expressed in Pauline and Augustinian terms as a spiritual and inward war, which divided people against their own selves. Rocheblave spells this out in another sermon: 'la chair et le sang, les principautés et les puissances, les hommes et les démons [...] s'opposent à nôtre salut [...]; nous sommes sans cesse aux prises avec nous-mêmes; la chair convoite contre l'esprit'.$^{58}$ This was, he thought, the true horror of the Fall, which shattered the integrated self of the state of innocence and left humans simultaneously longing for, and yet at war with, what is true and good and right, which is why the efforts of most preachers were frustrated, according to Rocheblave. They believed that 'pour inspirer aux hommes l'amour de la vérité, il suffit de leur en faire voir la beauté et l'excellence, et de leur représenter au contraire la laideur et les suites funestes du vice', forgetting to take account of 'la corruption du coeur et des

52 J. Claude, La Défense de la Réformation (Quevilly/Rouen, 1673), II.8, pp.183-84; II.9, pp.19597.

53 Rocheblave, Sermons, X, p.281; the verbs that recur consistently in this context referring either to preaching or hearing, or both, and sometimes qualified with adverbs such as 'profondement', 'souvent', are: 'apprendre', 'comprendre', 'considérer', 'contempler', 'examiner', 'instruire' 'méditer', 'se souvenir', 'penser', 'persuader'.

54 Rocheblave, Sermons, I, p.27; V, p.133; VI, p.153; VII, pp.182, 206; the verbs are 'contempler' (inner eye), 'montrer', 'regarder', 'représenter', 'voir', and, of course, 'illuminer', as in the following prayer, 'Pere des lumieres, illumine nos entendemens, afin que par ta clarté, nous puissions penétrer \& contempler avec joie les choses magnifiques de ton roiaume, ces choses qui apartiennent à nôtre paix' (p.182); sometimes the agent of illumination is Jesus Christ (p.187), and sometimes the Spirit (p.206).

55 Rocheblave, Sermons, VIII, p.216.

56 Gillespie, Reading Ireland, p.132.

57 Rocheblave, Sermons, VI, p.156 (also pp.154-55); see IV, p.91.

58 Rocheblave, Sermons, X, p.293, although he does not explicitly quote Scripture at this point, he is alluding to Romans 7-14-23; see also VII, pp.183-85. 
mauvaises dispositions de ceux qui $[\ldots]$ écoutent' ${ }^{59}$ Is Rocheblave including himself in this pessimistic assessment of the effects of preaching, hearing and reading? After all, he represents himself as someone engaged in making congregants see incorporeal truths.

In his sermons, Rocheblave enunciates a theory and practice of implicated reading ${ }^{60}$ that is designed to take account of the messy reality of human life. The warfare within postlapsarian humans tends to distract them from the gospel: 'les [...] passions criminelles [...] les empêchent de penser aux graces de Dieu', sometimes to the point of what he calls an 'insensibilité par raport aux bienfaits spirituels' ${ }^{61}$ So if readers are to be 'intangled' into an active apprehension of the Word, which is the ideal to which the Reformed tradition aspires, then that dark wildness of the heart - sometimes referred to as 'the flesh' that is at war with the spirit - must be addressed. And not addressed only, but also inwardly affected by what is read. Consequently, Rocheblave is convinced that inculcating the Word has to become more than a cognitive and interpretative act; it must also turn into an affective, even an emotionally disturbing, experience. He uses words like 'encourager', 'consoler', 'admirer', 'étonner', 'réjouir', and even 's'écrier avec un saint transport d'admiration', 'effrayer', épouvanter' 'craindre', to inscribe a network of emotional responses in his sermons that predispose hearerreaders to react in certain ways. ${ }^{62} \mathrm{He}$ tends to sum up such affective reactions more generally in terms of movement: 'il est tems de vous faire voir les mouvemens que cette consideration doit produire en nous, et l'influence qu'elle doit avoir sur la conduite de nôtre vie'; or 'pour vous porter plus efficacement à la pratique de ce devoir, considerez encore...' ${ }^{63}$ Although the means are cognitive and emotional, the end is moral; hearing, reading and preaching the Word should make hearer-readers adjust their outlook and behave differently. In sum, readers of Scripture are to become altered persons, and the sermon is one of the occasions when and one of the sites where transformative reading or hearing occurs. ${ }^{64}$ In Rocheblave's view, this kind of reading is only enabled by a particular kind of pulpit oratory. When he observes that sermons can often be fruitless, he means the kind of preaching that uses oratorical tropes, figures and flourishes to please and, in this way, to persuade, hearer-readers, and he dismisses this as a 'style pompeux et affecté' inappropriate to the gospel. ${ }^{65}$ It is inappropriate because it draws hearer readers into an aesthetic rather than a morally transforming experience, flattering rather than challenging them. ${ }^{66}$

By contrast, the commentary or exegetical sermon, which Rocheblave espouses, instructs and guides auditors into their own encounter with the Word. While he also uses rhetoric to achieve this, he confines himself to more functional modes, such as apostrophe, rhetorical questions, anaphora, exclamation,

59 Rocheblave, Sermons, VIII, pp.213-14.

60 I borrow this notion from Pearce, Feminism, pp.1-33.

61 Rocheblave, Sermons, III, p.82; also VII, p.181.

62 Rocheblave, Sermons, II, p.41, VII, pp.152, 180, 181; VIII, pp.214, 216; W. Iser, 'Interaction between text and reader', in S.R. Suleiman and I. Crosman (ed.), The reader in the text. Essays on audience and interpretation (Princeton, 1980), pp.107-08; Pearce, Feminism, p.2.

63 Rocheblave, Sermons, V,pp.133, 141.

64 Kort, 'Take, read', p.35, makes this point about reading Scripture.

65 Rocheblave, Sermons, IX, p.250, also VIII, pp.213-14.

66 R. Whelan, 'Sin, style and sensibility, or the controversy over rhetoric and preaching in the $1690 \mathrm{~s}$ ', Studies on Voltaire and the eighteenth century, 320 (1994), pp.145-61, and idem, "'The foolishness of preaching", pp.289-300. 
repetition, all designed to move hearers and make them participate in the sermon as implicated readers rather than detached observers of its aesthetic or other merits. Central to this purpose is the dialectical presentation that Rocheblave favours, which is inspired by an essentially antithetical or polarised worldview: hell and heaven, flesh and spirit, sin and grace, death and life, fall and redemption, error and truth, bondage and freedom, idolatry and true religion, evil and good, godless and godly, Antichrist and Christ, devil and God. Time and again Rocheblave draws his auditors into these antitheses, sometimes attaching them either directly or indirectly to the positive pole, sometimes leaving them to place themselves on one side or the other, and, on occasion, stranding them on the negative pole by a sudden switch of personal pronoun from 'ils' or 'eux', to 'vous' or 'nous'. ${ }^{67}$ In this way, they are brought to experience in the real time of the sermon the split-self that results from the Fall, to witness ex auditu, and actually to feel, the inward war that divides them against themselves. ${ }^{68}$ Rocheblave quite deliberately engages hearers in a process of hearing/reading Scripture that dislocates, displaces and disturbs them, opening them up to the possibility of fresh insight and alternative ways of being. In a word, he creates split hearer-readers and makes the sermon a site of potential integration, where congregants confront rather than elude or conceal their own contradictions. ${ }^{69}$

What this means, of course, is that Rocheblave's preaching 'intangles' hearer readers into the inevitability of choice, ${ }^{70}$ as the overall structure of his sermons illustrates. He usually organises his exegesis of the biblical passage into two parts, which are preceded by an exordium or introduction and concluded with what he refers to as the 'application', where he exhorts readers to apply the teaching of Scripture to their own lives. In other words, the structure of his sermons is a controlled environment, where hearer-readers are drawn into learning by doing. While they do not do this by themselves, but rather collectively with their minister as guide, they do carry out this process for themselves. Rocheblave likes to state his role as enabler, observing 'pour donner à vôtre pieté le secours qu'elle demande de nous en cette occasion, je diviserai mon discours ...', and expresses his confidence that ordinary people can engage in this spiritual exercise. ${ }^{71}$ The process is one of intense self-scrutiny in the light of the Word: 'apliquez-vous à la lecture et à la méditation de la Parole de Dieu, qui vous aprendra parfaitement vos devoirs et vos esperances; $[. .$.$] examinez$ souvent toute vôtre conduite'; 'étudions-nous à nous corriger de nos vices, et à faire en toutes choses la volonté de Dieu'.72 Obviously, all true readings of Scripture involve $\mu \varepsilon \tau \dot{\alpha}$ vol $\alpha$, that is, repentance, an interactive relationship with the ultimate Author, which turns readers around, changes them, converts them, guiding them through life unto death and beyond. ${ }^{73}$ Although Rocheblave holds preachers and hearers individually responsible for this reading without end, as a

67 I am applying to Rocheblave's preaching some of the findings of S.E. Fish, Self-consuming artefacts (Berkeley and Los Angeles, 1972), pp.1-3; also idem, Surprised by sin, pp.1-61.

68 On the 'network of response-inviting structures' that shape the role to be assumed by the reader, see W. Iser, The act of reading: a theory of aesthetic response (Baltimore and London, 1978), p.34.

69 Fish, Surprised by $\sin , \mathrm{p} .42$.

70 Rocheblave, Sermons, p.90.

71 Rocheblave, Sermons, VI, p.153; VII, p.194.

72 Rocheblave, Sermons, VIII, pp.244-45; VII, p.207

73 Rocheblave, Sermons, VII, pp.193, 202-5; VIII, pp.220-22; V, p.149. 
Reformed minister, he insists that ultimately it is God 'qui nous convertit'; 'c'est la Parole [...] qui sauve nos âmes' ${ }^{74}$ While there can be no saving knowledge of God without Scripture, the power to save is not in the biblical text itself but in the one who is its assumed Author ${ }^{75}$ In other words, Rocheblave is communicating a theological understanding of the Bible to congregants that has the potential to channel the multiple ways people position and reposition themselves in relation to texts into a dominant hearer-reader-positioning. ${ }^{76}$ If the many narrative voices that make up the Scriptures all come from the one divine mouth, then it is in congregants' interest to respond by aligning themselves with the God who is presumed to be speaking.

The liturgical context of Rocheblave's preaching plays a vital part in that positioning, setting up the conditions that prompt congregants to actualise what they hear or read. ${ }^{77}$ At the risk of stating the obvious, reading, hearing, singing, and preaching the Bible occurred in services of worship, to which people came already disposed to revere a God whom they presumed real and present, and who was 'made real', as it were, by their performative actions, gestures and language. Moreover, preaching actually performed an I-Thou, dialogic way of hearing and reading, at one level between minister, Word and people, and, at another invisible yet no less real level, between God - whose words the minister believed he was explicating - and people. This dialogic act of hearing and reading also constituted them as religious subjects, as the 'thou' to whom the words of the ultimate 'I' were addressed, creating separateness, a space within the self and the community in which that dialogue could potentially occur. ${ }^{78}$ And it did occur within the service; inwardly, if people responded to the Word in the echo chambers of their own hearts, but also outwardly and performatively in the congregational singing of the psalms. As they sang unaccompanied, yet lustily, they made the words of the psalmist their own, mingling that incorporeal energy with their own bodies and addressing God in the second person singular, as 'tu', thereby positioning themselves as intimate interlocutors of the one to whom they sang; intimate but not equal. ${ }^{79}$ Significantly, Rocheblave represents God as both loving other (father, lover, friend, saviour, redeemer, attentive presence) and sovereign judge ('le souverain dominateur de toutes choses'), whose unwavering gaze strikes awe in all he (because Rocheblave's God is resolutely male) surveys. ${ }^{80}$ All acts of communication are power-inscribed ${ }^{81}$ but none more than a liturgy, where the presence of the transcendent other in - or even as - the text, positions hearer readers as subordinate, and their responses as reactive and essentially motivated by desire and fear. At one level, congregants can respond variously, but at another, their response is already scripted to the text-as-God(-

74 Rocheblave, Sermons, VIII, pp.239, 221; VII, pp.207, 197, 199, 202-3, 206; Steiner, Real Presence, p.83.

75 Kort, 'Take, read', p.26, makes a similar observation concerning Calvin's understanding of Scripture reading.

76 I borrow this notion from Pearce, Feminism, p.38.

77 On the concept of 'conditions of actualisation', see Iser, Act of reading, p.34; on the 'actualising' properties and performativity of ritual, see P. Connerton, How Societies Remember (Cambridge, 1989), pp.66-68.

78 Pearce, Feminism, p.26; Certeau, 'Lecture absolue', p.71.

79 Rocheblave, Sermons, V, p.149; Steiner, Real Presence, p.19.

80 Rocheblave, Sermons, I, p.2; the metaphor of God as 'Dominateur' is present in French Reformed liturgy in this period.

81 Pearce, Feminism, p.27. 
lover-and-judge)-speaking. They are called to respond with answering answerability.

It is possible to reach some overall conclusions from Rocheblave's extant sermons concerning the kinds of answerability that he was scripting for the Dublin Huguenots who heard him preach. Broadly speaking, the attitudes he seeks to shape and the responses he tries to invoke in his hearer-readers fall into three categories - doctrinal, moral and political - which he develops according to the polarisations that typify his worldview. However, one antithesis weaves all of these together, namely that of bondage and freedom. ${ }^{82}$ Like Calvin before him, Rocheblave believed that the knowledge of God was the foundation of all religion, ${ }^{83}$ but only if that knowledge was true. Throughout his sermons, he is concerned to expound that truth, as he sees it, which, as we might expect, he limits to 'la verité, la divinité du Christianisme', without which 'nôtre foi sera une foi aveugle [...] une foi morte' ${ }^{84}$ At times he preaches catechetically, discoursing on God as first cause, as Providence, as Judge, as Trinity, as Saviour in Jesus Christ, outlining Reformed notions of grace, substitutionary atonement, or the afterlife for the benefit of congregants. Commonplace as they are, Rocheblave's views are at times explicitly polemical. Although he insists that congregants should understand what they believe, he also asserts that Christianity is essentially mysterious, and speaks out against 'certains Esprits téméraires', who were urging people to reject anything they found inconsistent with reason ${ }^{85}$ He may be referring to the public disquiet that followed the publication of John Toland's subversive Christianity not mysterious (London, 1696), which continued to preoccupy the elite in Dublin and elsewhere in the early eighteenthcentury. Rationalism is not his only target, however. In another sermon, the polarisations between Christ and Antichrist, true religion and idolatry are transposed by allusion to the cult of saints and holy objects, into an opposition between Reformed and Roman Catholic forms of worship. ${ }^{86}$ In Rocheblave's symbolic world, both rationalism and idolatry are forms of bondage, both linked to the fallen, sinful condition of human beings by the lexis he uses to describe them.$^{87}$ Of course, the presence of that lexis indicates that while Rocheblave is 'intangling' his reader-hearers in Scripture, he is also concerned to script their responses according to an authorised, clerical reading that is conservatively Protestant.

A similar mechanism can be observed when Rocheblave draws out the moral lessons of Scripture for his hearer-readers. As might be expected, he presents the Reformed tradition as the true faith, clothing it in the language of liberty and light, holiness and happiness as opposed to the bondage of rationalism or Catholicism - but the liberty he preaches is paradoxical. He asserts that Jesus

82 Rocheblave, Sermons, VII, p.184-88.

83 Rocheblave, Sermons, IV, p.90. J. Calvin, Institutes of the Christian religion, ed. J.T. McNeill; tr. F.L. Battles (2 vols., Philadelphia, 1960), 1.1.1-ii, pp.35-43.

84 Rocheblave, Sermons, VII, p.206.

85 Rocheblave, Sermons, IV, p.105; also IX, pp.271-72.

86 Rocheblave, Sermons, V, pp.145-146; X, p.298, for a denunciation of the Catholic doctrine of Purgatory.

87 The lexis associated with rationalism: 'téméraire', 'faux et extrémement dangereux', 'pernicieux' 'Esprits superbes', 'folie', 'une présomption, un orgueil insuportable' (Sermons, IV, pp.105-06) links it to the sin of pride; idolatry, of course, contravenes the first order of the Decalogue, and is linked by Rocheblave to the seduction the Devil exercises over human beings, drawing them into actions 'les plus barbares, les plus monstrueuses' (Sermons, VII, p.185-86). 
Christ is 'le grand liberateur promis par les prophetes', 'le fils de Dieu [qui] nous rend véritablement libres' because he delivers humans from enslavement to their own conflicted selves, from sin, death, idolatry, evil, and eternal perdition. ${ }^{88}$ Yet, he argues, believers enter into that freedom by attitudes of submission and obedience: 'la vraie foi est toûjours accompagnée de l'obéissance aux préceptes de l'Evangile'; 'la foi en Jésus-Christ n'est jamais separée de l'observation exacte de sa parole, et [...] elle nous fait soumettre à toutes les maximes de sa religion' ${ }^{89}$ Ideally the paradox of submissive freedom or free submission in response to the Word should result in lives that glorified their 'Liberateur' and 'Protecteur' by 'une conduite pure, chaste, et reglée'. ${ }^{90}$ In reality, as we have seen, the ordered, moral life evades postlapsarian humans unless they are empowered to resist the temptations that beset them. But they were so empowered, according to Rocheblave, who proclaims 'il [Dieu] peut vous remplir interieurement de force et de courage [...] vous serez inébranlables, au milieu des plus terribles tentations' ${ }^{91}$ From this point of view, preaching, hearing and reading the Scriptures are educational processes which frame and reframe experience, orienting it toward a particular understanding of the good life which the ministers believed was to be found in the Bible. Although these processes are also sites of potential renewal, because hearer-readers are cued into the selfbelief needed for new beginnings, any transformation they might embrace is circumscribed in advance by the very act in which they are engaging. To put it another way, in as much as hearer-readers are being taught by their minister how to respond, they are engaging not with the biblical text directly but with paradigms that shape and regulate both their minister's and hence their own perception of the text. ${ }^{92}$

One of those paradigms is political. In the two sermons that open the volume the polarisation between bondage and freedom is politicised, creating an opposition between the 'nations infidelles et idolatres' and the 'Eglise' or the 'peuple de Dieu', which Rocheblave links to the defeat of the French by the Anglo-German Grand Alliance at Oudenaarde on 11 July 1708 during the War of the Spanish Succession. And he exhorts those who are listenng to him to 'benir Dieu de ce que, par sa sage et misericordieuse providence, il a dissipé [...] les projets et les machinations de nos ennemis, qui avoient pour but d'envahir les etats de Sa Majesté, de causer une guerre civile dans ces Roiaumes, et de détruire nos libertez et nôtre sainte religion'. The kingdoms in question are Britain and Ireland, which Rocheblave presents as islands of happy, unadulterated Protestantism: 'ces païs heureux, où la vérité et son culte regnent sans aucun mélange d'erreur, de supersition et d'idolatrie', which are portrayed as holding out against 'l'ennemi commun', also described as 'les ennemis de l'église'. ${ }^{93}$ Theology, ideology and politics intersect turning the war into a conflict of heaven against hell, 'la véritable religion, contre un culte faux et idolatre', 'les droits et la

88 Rocheblave, Sermons, VI, p.174; VII, pp.185-87.

89 Rocheblave, Sermons, VII, p.198, 199; see 193-197.

90 Rocheblave, Sermons, I, p.27.

91 Rocheblave, Sermons, VIII, p.231.

92 A. Kolodny, 'Dancing through the minefield: some observations on the theory, practice, and politics of a feminist literary criticism', Feminist studies, 6 (1980), pp.10-12.

93 Rocheblave, Sermons, II, pp.28, 31, 39, 49, 53; E. Cameron (ed.), Early modern Europe. An Oxford history (Oxford, 2001), pp.224-25, for the defeat of the French in 1708 . 
liberté commune du genre humain, contre la tyrannie et l'oppression' ${ }^{94}$ All the commonplaces of anti-Catholic rhetoric are present here, equating Catholicism with sedition, tyranny, and oppression, and communicating a fear of Catholic designs upon liberty and true religion. When Rocheblave urges his hearer-readers to celebrate the defeat of the (Catholic) French at Oudenaarde as a Providential intervention on behalf of liberty, whether of British Protestants or the entire human race he is 'intangling' them not so much in a biblical as a social text, which binds them into a teleology of national and cultural redemption that is unselfconsciously sectarian. In Rocheblave's preaching, anti-Catholicism has the potential to forge in Ireland an explicitly Protestant bonding between foreign French refugees and the receiving society (the Protestant minority), by the way it constructs a shared loathing of popery and the tyranny it is thought to promote..$^{95}$

The protocols of reading embedded in the sermons of Henri de Rocheblave point, therefore, to 'the ambiguous mastery of texts over life', to borrow George Steiner's phrase. ${ }^{96}$ On the one hand, when Huguenots became hearer-readers of the Bible in response to his preaching, they were learning what it was like, or what it might be like, to be somewhere else, where they heard the voice of their God. ${ }^{97}$ And, as we have seen, that interaction was meant to be transformative, whether personally or collectively. On the other hand, Rocheblave attempts to contain that transformation within safely normative interpretations of the doctrinal, moral and political implications of the Bible, which he frames in terms of a polarised worldview. What this means is that reading and hearing the Bible was subsumed under a set of interests that, at times, determined how the Bible was to be read. Scripture reading at this juncture becomes an act of appropriation of the biblical text in a process of identity formation and validation, which particularly in political matters - is predicated on excluding others, making a place where they are not. ${ }^{98}$ Unwittingly, this expresses a failure in the theory of Bible reading that is scripted in the sermons. The reading without end, which is the Reformed reading of Scripture, is designed to bring all, without exception, under the authority of the text, and to open the self, group, institution, or system to the scrutiny and questioning of the Book-as-God-speaking. That in one crucial respect, at least, the Huguenots were blind to that imperative goes without saying, since we witness them projecting outward the fears generated from the dark wildness of their hearts with a certainty that resists interrogation. Of course, the polarisations at work are understandable, given French Protestants' experience of persecution in Catholic France, but polarisations are all potential forms of violence. ${ }^{99}$ To preach in this way in Dublin in the early eighteenth century was to mark the complicity of Huguenot pastors, and possibly their congregants, in a culture of political exclusion of the much more numerous Irish

94 Rocheblave, Sermons, I, p.11

95 I am applying to Rochebalve the findings of R.D. Tumbleson, Catholicism in the English Protestant imagination. Nationalism, religion, and literature, 1660-1745 (Cambridge, 1998), pp.4-5.

96 Steiner, Real Presence, p.193.

97 Kort, 'Take, read', p.113.

98 M. de Certeau, 'Lire un braconnage', in L'invention du quotidien. Actes de faire (Saint-Amand, 1980), p.291.

99 Kort, 'Take, read', p.133. 
Catholics. ${ }^{100}$ By allowing their unquestioned assumptions to determine their reading of Scripture, they appropriated the biblical text in such a way as to turn a potentially liberating theory into an instrumental practice of reading that lent itself to demonising the other and, on the international scale, justifying the violence of war.

Reading, as Susan Suleiman remarked, is a context-specific act. ${ }^{101}$ The social and political context of Rocheblave's reading and preaching of the Bible point to at least some of the reasons why 'Protestant' Bibles and sermons found their way onto lists of prohibited books in seventeenth- and eighteenth-century France. The royal commissioners and spies who were not infrequently present at Reformed services in France before the Revocation had the opportunity to witness the way preaching symbolically inscribed French Protestants into sacred history, giving them a sense of themselves as the people of God, of whom and to whom the Scriptures spoke. A short report made on 11 July 1685 to La Reynie (lieutenant general of police) by an informant planted in the Charenton temple, suggests that the authorities were aware of the way that symbolic representation could fuel Huguenot resistance to forcible assimilation to Catholicism. Significantly, the spy comments on a sermon preached at Easter by Élie Bertheau, formerly pastor at Montpellier, ${ }^{102}$ observing: 'Il parla de la démolition des temples, et dit entre autres choses que, si on privait les fidèles de ces temples matériels, chacun d'entr'eux devait faire un temple dans son coeur pour y adorer Dieu, et que l'on ne pourrait détruire ce temple qu'en leur ôtant la vie' ${ }^{103}$ Reading, preaching and hearing the Scriptures helped to create a place apart, that inner temple of which Élie Bertheau spoke, which grounded the Huguenots' sense of difference in a religious and polarised worldview. When they became refugees, they turned among other things to their Bibles to try to make sense of what had occurred; "in dispersion the text is homeland', as George Steiner observed of Judaism. ${ }^{104}$ However, that homeland was not an unmediated but rather a normative text, enunciated by preachers like Henri de Rocheblave, whose interpretation of Scripture was as political as it was theological. His preaching in early eighteenthcentury Dublin reveals some of the ways the Bible became part of an ideology that may have fed resistance to the military power of France while uniting Protestants of diverse geographical origins in a shared identity in the land they were making their home.

National University of Ireland, Maynooth

Ruth Whelan

$100 \mathrm{R}$. Whelan, 'Persecution and Toleration: the Changing Identities of Ireland's Huguenot Refugees', HSP 27/1 (1998), pp.20-35 and idem, 'Repressive Toleration: the Huguenots in Early Eighteenth-century Dublin', in Whelan and Baxter (ed.), Toleration and religious identity, pp.179-95.

101 S.R. Suleiman, 'Introduction: varieties of audience oriented criticism', in The reader in the text, p.44-45.

102 S. Mours, 'Les pasteurs à la Révocation de l'Edit de Nantes', Bulletin de la Société de l'histoire du protestantisme français 114 (1968), p.298.

103 Quoted by Douen, Révocation, iii, pp.555-56.

104 Steiner, Real Presence, p.40. 